\title{
Immunotherapy for non-small cell lung cancers: biomarkers for predicting responses and strategies to overcome resistance
}

\author{
Xingxiang $\mathrm{Pu}^{1,2}$, Lin $\mathrm{Wu}^{2}$, Dan $\mathrm{Su}^{3}$, Weimin Mao ${ }^{4}$ and Bingliang Fang ${ }^{1 *}$
}

\begin{abstract}
Recent breakthroughs in targeted therapy and immunotherapy have revolutionized the treatment of lung cancer, the leading cause of cancer-related deaths in the United States and worldwide. Here we provide an overview of recent progress in immune checkpoint blockade therapy for treatment of non-small cell lung cancer (NSCLC), and discuss biomarkers associated with the treatment responses, mechanisms underlying resistance and strategies to overcome resistance. The success of immune checkpoint blockade therapies is driven by immunogenicity of tumor cells, which is associated with mutation burden and neoantigen burden in cancers. Lymphocyte infiltration in cancer tissues and interferon- - -induced PD-L1 expression in tumor microenvironments may serve as surrogate biomarkers for adaptive immune resistance and likelihood of responses to immune checkpoint blockade therapy. In contrast, weak immunogenicity of, and/or impaired antigen presentation in, tumor cells are primary causes of resistance to these therapies. Thus, approaches that increase immunogenicity of cancer cells and/or enhance immune cell recruitment to cancer sites will likely overcome resistance to immunotherapy.
\end{abstract}

Keywords: Immune checkpoint inhibitors, PD-1, PD-L1, Predictive biomarkers, Resistance

\section{Introduction}

Recent breakthroughs in immunotherapy for cancer have changed clinical practice in the treatment of lung cancer, a deadly disease that each year causes about 155,000 deaths in the United States and approximately 1.6 million deaths worldwide $[1,2]$. Since 2015 , four immune checkpoint inhibitors (ICIs), anti-PD-1 antibodies nivolumab $[3,4]$ and pembrolizumab $[5,6]$ and antiPD-L1 antibody atezolizumab [7] and durvalumab $[8,9]$, were approved for treatment of non-small cell lung carcinoma (NSCLC) by the United States Food and Drug Administration (FDA). Nivolumab [10] and atezolizumab [11] were approved in 2015 and 2016, respectively, as second-line therapies for patients with advanced NSCLC that progressed after or during platinum-based chemotherapy. Pembrolizumab was approved in 2015 as

\footnotetext{
* Correspondence: bfang@mdanderson.org

${ }^{1}$ Department of Thoracic and Cardiovascular Surgery, The University of Texas MD Anderson Cancer Center, Houston, TX 77030, USA

Full list of author information is available at the end of the article
}

a second-line therapy for patients with advanced NSCLC with PD-L1 expression of $\geq 1 \%$ [12]. In 2016, pembrolizumab was approved as a first-line therapy for NSCLC with PD-L1 expression of $\geq 50 \%$ in tumor tissues and for advanced NSCLC which has PD-L1 expression of $\geq 1 \%$ and has disease progression on or after platinum-containing chemotherapy [12]. More recently, pembrolizumab in combination with pemetrexed and carboplatin was approved by the FDA as first-line therapy for NSCLC [13], while durvalumab was approved for treatment of patients with unresectable stage III NSCLC whose cancer have not progressed following treatment with chemotherapy and radiation $[8,9]$.

Clinical trials have revealed that using anti-PD immunotherapy for patients with advanced NSCLC led to improved clinical outcomes, including improved survival rates, prolonged duration of response, and reduced treatment-related adverse effects [14]. However, although anti-PD-1 and anti-PD-L1 therapies have shown unprecedented durable responses in some NSCLC

(c) The Author(s). 2018 Open Access This article is distributed under the terms of the Creative Commons Attribution 4.0 International License (http://creativecommons.org/licenses/by/4.0/), which permits unrestricted use, distribution, and reproduction in any medium, provided you give appropriate credit to the original author(s) and the source, provide a link to the Creative Commons license, and indicate if changes were made. The Creative Commons Public Domain Dedication waiver (http://creativecommons.org/publicdomain/zero/1.0/) applies to the data made available in this article, unless otherwise stated. 
patients, emerging data from clinical trials with anti-PD therapy also revealed that only about $15-25 \%$ of NSCLC patients responded to immune checkpoint blockage therapy $[3-5,7]$, and most had primary resistance. Thus, predictive biomarkers need to be identified for patient stratification in order to maximize the therapeutic benefit of immune checkpoint blockade therapy; furthermore, approaches to overcome resistance to this anticancer immunotherapy are highly desirable in order to broaden the patient populations who can benefit from this therapy. This review discusses recent progress in translational and clinical investigation of immune checkpoint blockade therapy for lung cancer and factors associated with the treatment responses. We first review the currently available immune checkpoint blockade therapies for treatment of non-small cell lung cancer (NSCLC), and then discuss biomarkers associated with the treatment responses, and analyze possible mechanisms underlying resistance and strategies to overcome resistance.

Clinical responses to immune checkpoint inhibitors in NSCLC Since 2015, four PD-1/PD-L1 inhibitors (nivolumab, pembrolizumab, atezolizuma and durvalumab) have been approved by the FDA as second-line therapy and/or first-line therapy for NSCLC. In addition, anti-PD-L1 antibody avelumab [15] is being evaluated extensively in clinical trials for treatment of NSCLC.

Nivolumab is a human antibody (IgG4) specific for human PD-1. It binds PD-1 with high affinity and prevents interaction of PD-1 with its ligands PD-L1 or PD-L2, thereby enhancing tumor antigen-specific $\mathrm{T}$ cell proliferation [16]. The human IgG4 immunoglobulin subtype interacts poorly with Fc receptors (FcyRII and FcyRIII) and complement [17], and thus causing minimal antibody-dependent cell-mediated cytotoxicity and/or complement-induced cytotoxicity to the $\mathrm{T}$ cells to be activated. In phase 1 and 2 trials, nivolumab showed durable antitumor activity and a cumulative response rate of about $18 \%$ in all NSCLC subtypes [18-20]. In two phase 3 studies comparing the efficacies of nivolumab versus docetaxel in advanced squamous (CheckMate 017) [4] and nonsquamous (CheckMate 057) [3] NSCLC that were resistant to platinum-based therapy, nivolumab was found to be significantly better than docetaxel in response rate, overall survival, and progression-free survival, regardless of intratumoral PD-L1 expression levels. The overall response rate was $19-20 \%$ in the nivolumab treated group versus $9-12 \%$ in docetaxel treated group (Table 1). Based on those results, nivolumab was approved by the FDA in 2015 as a second-line monotherapy for advanced squamous cell and non-squamous cell NSCLC.

Pembrolizumab (KEYTRUDA) is a humanized IgG4 monoclonal antibody specific for human PD-1. In a randomized phase 2 and 3 trial (KEYNOTE-010) with 1034
NSCLC patients who were previously treated with chemotherapy and were PD-L1-positive in tumor cells based on immunohistochemical analysis $(\geq 1 \%)$ [21] (Table 1), patients were randomly assigned to three arms: pembrolizu$\mathrm{mab}$ at $2 \mathrm{mg} / \mathrm{kg}$, pembrolizumab at $10 \mathrm{mg} / \mathrm{kg}$, and docetaxel at $75 \mathrm{mg} / \mathrm{m}^{2}$. The results showed that, among patients with at least $50 \%$ of tumor cells expressing PD-L1, overall survival (OS) and progression-free survival (PFS) were significantly longer in the group treated with pembrolizumab at $2 \mathrm{mg} / \mathrm{kg}$ than the group treated with docetaxel (median OS was 14.9 months vs 8.2 months, respectively; median PFS 5.0 months vs 4.1 months, respectively) and with pembrolizumab at $10 \mathrm{mg} / \mathrm{kg}$ than with docetaxel (median OS was 17.3 months vs 8.2 months, respectively; median PFS 5.2 months vs 4.1 months, respectively) [21]. In another phase 3 trial (KEYNOTE-024) with 305 advanced NSCLC patients who were not previously treated and had no sensitizing mutation for target therapies in their tumors but had at least 50\% PD- $\mathrm{L}^{+}$tumor cells, patients were randomly assigned to the treatment with either pembrolizumab (200 mg every 3 weeks) or platinum-based chemotherapy [22]. The results revealed that both PFS and estimated OS at 6 months were significantly improved in pembrolizumab treated group than in the chemotherapy group. The response rate was about $45 \%$ in the pembrolizumab group vs approximately $28 \%$ in the chemotherapy group. Those results led to pembrolizumab's approval as second-line therapy for metastatic NSCLC with PD-L1 expression of $\geq 1 \%$ and first-line therapy for NSCLC with expression of PD-L1 of $\geq 50 \%$.

Atezolizumab is an anti-PD-L1 antibody that previously approved by the FDA for the treatment of urothelial carcinoma that progresses after platinum-based chemotherapy. Atezolizumab was recently approved as a second-line therapy for patients with metastatic NSCLC based on two international trials (OAK and POPLAR, Table 1) with a total of 1137 NSCLC patients, which demonstrated consistent results in efficacy and safety atezolizumab in treatment of NSCLC [7, 23]. In comparison with docetaxel, treatment with atezolizumab led to a $2.9 \sim 4.2$ month improvement in OS in these two trials. The median OS was about 13 months in the atezolizumab treated group compared with about 9.6 months in the docetaxel treated group $[7,23]$. The improvement in OS was associated with increased expression of PD-L1 in tumor cells and increased tumor-infiltrating immune cells [23].

Durvalumab is a PD-L1 specific human IgG1 monoclonal antibody [24] that contains three point mutations in the constant domain for minimized binding to complement and Fc receptors [25]. Durvalumab was recently approved for treatment of patients with locally advanced or metastatic urothelial carcinoma who have disease progression during or following platinum-containing chemotherapy [26]. In a phase III trial (PACIFIC) of 709 
Table 1 Clinical trials on immune checkpoint inhibitors in non-small cell lung cancer

\begin{tabular}{|c|c|c|c|c|c|c|c|}
\hline $\begin{array}{l}\text { Name of } \\
\text { trial }\end{array}$ & Phase & $\begin{array}{l}\text { Histology/ line of } \\
\text { treatment }\end{array}$ & Randomization & No. Cases & First end point results & ORR (RECIST) & $\begin{array}{l}\text { Effect of PD-L1 } \\
\text { expression }\end{array}$ \\
\hline $\begin{array}{l}\text { CheckMate } \\
017\end{array}$ & III & $\begin{array}{l}\text { SqNSCLC/ } \\
\text { second }\end{array}$ & $\begin{array}{l}\text { Nivolumab at } \\
3 \mathrm{mg} / \mathrm{kg} \text { vs. } \\
\text { docetaxel at } \\
75 \mathrm{mg} / \mathrm{m}^{2}\end{array}$ & 272 & $\begin{array}{l}\text { Significant improvement } \\
\text { in OS for patients } \\
\text { receiving nivolumab } \\
\text { compared with docetaxel } \\
\text { (median, } 9.2 \text { vs. } 6.0 \text { mo; } \\
\text { HR, } 0.59 ; p<.001 \text { ). }\end{array}$ & $\begin{array}{l}\text { Response rate was } \\
20 \% \text { with nivolumab } \\
\text { vs. } 9 \% \text { with docetaxel } \\
(P=0.008)\end{array}$ & $\begin{array}{l}\text { PD-L1 expression } \\
\text { was neither } \\
\text { prognostic nor } \\
\text { predictive for } \\
\text { efficacy end points }\end{array}$ \\
\hline $\begin{array}{l}\text { CheckMate } \\
057\end{array}$ & III & $\begin{array}{l}\text { Non-SqNSCLC/ } \\
\text { second }\end{array}$ & $\begin{array}{l}\text { Nivolumab at } \\
3 \mathrm{mg} / \mathrm{kg} \text { vs. } \\
\text { docetaxel at } \\
75 \mathrm{mg} / \mathrm{m}^{2}\end{array}$ & 582 & $\begin{array}{l}\text { Significant improvement in } \\
\text { OS for patients receiving } \\
\text { nivolumab compared with } \\
\text { docetaxel (median } 12.2 \text { vs. } \\
9.4 \text { mo; HR, } 0.73 ; p=.002 \text { ). }\end{array}$ & $\begin{array}{l}\text { Response rate was } \\
19 \% \text { with nivolumab } \\
\text { vs. 12\% with docetaxel } \\
(P=0.02)\end{array}$ & $\begin{array}{l}\text { PD-L1 expression } \\
\text { was associated } \\
\text { with even greater } \\
\text { efficacy at all } \\
\text { expression levels } \\
(\geq 1 \%, \geq 5 \% \text {, and } \\
\geq 10 \%) \text {. }\end{array}$ \\
\hline $\begin{array}{l}\text { KEYNOTE } \\
010\end{array}$ & $\|/\| \|$ & $\begin{array}{l}\text { NSCLC PD-L1- } \\
\text { positive tumors } \\
(\text { PS } \geq 1 \%) / \text { second }\end{array}$ & $\begin{array}{l}\text { Pembrolizumab } \\
\text { at } 2 \mathrm{mg} / \mathrm{kg} \text { or } \\
10 \mathrm{mg} / \mathrm{kg} \text { vs. } \\
\text { docetaxel } \\
75 \mathrm{mg} / \mathrm{m}^{2}\end{array}$ & 1034 & $\begin{array}{l}\text { Significant improvement } \\
\text { in OS for pembrolizumab } \\
\text { at } 2 \mathrm{mg} / \mathrm{kg} \text { (median } \\
10.4 \mathrm{vs} .8 .5 \mathrm{mo} \text {; HR, 0.71; } \\
p=.0008 \text { ) and } \\
\text { pembrolizumab at } \\
10 \mathrm{mg} / \mathrm{kg} \text { (median, } \\
12.7 \mathrm{vs} .8 .5 \mathrm{mo} \text {; HR, } 0.61 ; \\
p<.001 \text { ) compared } \\
\text { with docetaxel }\end{array}$ & $\begin{array}{l}\text { Response rate } \\
\text { was } 18 \% \text { with } \\
\text { pembrolizumab } \\
(2 \mathrm{mg} \text { and } 10 \mathrm{mg} \text { vs. } \\
9 \% \text { with docetaxel } \\
(P=0.0005 \text { and } 0.0002)\end{array}$ & $\begin{array}{l}\text { Pembrolizumab } \\
\text { efficacy was } \\
\text { greater in patients } \\
\text { with tumor PS } \geq 50 \%\end{array}$ \\
\hline $\begin{array}{l}\text { KEYNOTE } \\
024\end{array}$ & III & $\begin{array}{l}\text { NSCLC, PD-L1- } \\
\text { positive tumors } \\
\text { (PS } \geq 50 \% \text { ), no } \\
\text { sensitizing mutation } \\
\text { of EGFR or } \\
\text { translocation } \\
\text { of ALK/first }\end{array}$ & $\begin{array}{l}\text { Pembrolizumab } \\
\text { at fixed dose of } \\
200 \text { mg or } \\
\text { platinum-based } \\
\text { chemotherapy }\end{array}$ & 305 & $\begin{array}{l}\text { Significant improvement } \\
\text { in PFS for patients } \\
\text { receiving pembrolizumab } \\
\text { compared with } \\
\text { chemotherapy (median } \\
10.3 \text { vs. } 6.0 \text { mo; HR, } 0.5 \text {; } \\
p<.00001 \text { ). }\end{array}$ & $\begin{array}{l}\text { Response rate was } \\
44.8 \% \text { with } \\
\text { pembrolizumab vs. } \\
27.8 \% \text { with } \\
\text { chemotherapy }\end{array}$ & $\begin{array}{l}\text { All patients, PD-L1 } \\
\text { expression on at } \\
\text { least } 50 \% \text { of tumor } \\
\text { cells }\end{array}$ \\
\hline POPLAR & $\|$ & NSCLC/ second & $\begin{array}{l}\text { Atezolizumab } \\
1200 \mathrm{mg} \text { vs. } \\
\text { docetaxel } \\
75 \mathrm{mg} / \mathrm{m}^{2}\end{array}$ & 287 & $\begin{array}{l}\text { Significant improvement } \\
\text { in OS for patients } \\
\text { receiving atezolizumab } \\
\text { compared with docetaxel } \\
\text { (median, } 12.6 \text { vs. } 9.7 \text { mo; } \\
\text { HR, } 0.73 ; P=.04 \text { ) }\end{array}$ & $\begin{array}{l}\text { Objective responses } \\
\text { with atezolizumab } \\
\text { were durable, with a } \\
\text { median duration of } \\
14.3 \text { months ( } 95 \% \mathrm{Cl} \\
11 \cdot 6 \text {-non-estimable) } \\
\text { compared with } \\
7 \cdot 2 \text { months (5.6-12.5) } \\
\text { for docetaxel }\end{array}$ & $\begin{array}{l}\text { As with OS, PFS } \\
\text { and ORR tended } \\
\text { to show increased } \\
\text { atezolizumab benefit } \\
\text { with increasing } \\
\text { PD-L1 expression. }\end{array}$ \\
\hline OAK & III & NSCLC/ second & $\begin{array}{l}\text { Atezolizumab at } \\
1200 \mathrm{mg} \text { vs. } \\
\text { docetaxelat } \\
75 \mathrm{mg} / \mathrm{m}^{2}\end{array}$ & 850 & $\begin{array}{l}\text { Significant improvement in } \\
\text { OS for patients receiving } \\
\text { atezolizumab compared } \\
\text { with docetaxel (median } 13.8 \\
\text { vs. } 9.6 \text { mo; HR, 0.73; } \\
P=.0003 \text { ). }\end{array}$ & $\begin{array}{l}\text { For } 1 T \text { population, } \\
\text { response rate was } \\
14 \% \text { with atezolizumab } \\
\text { vs. } 13 \% \text { with docetaxel }\end{array}$ & $\begin{array}{l}\text { Overall survival was } \\
\text { improved regardless } \\
\text { of PD-L1 expression } \\
\text { levels. Patients with } \\
\text { tumors expressing } \\
\text { high levels of PD-L1 } \\
\text { (TC3 or IC } 3 \text { ) derived } \\
\text { the greatest benefit } \\
\text { from atezolizumab }\end{array}$ \\
\hline PACIFIC & III & $\begin{array}{l}\text { Stage III NSCLC with } \\
\text { no disease progression } \\
\text { after } \geq 2 \text { cycles of } \\
\text { chemoradiotherapy/ } \\
\text { second }\end{array}$ & $\begin{array}{l}\text { Durvalumab at } \\
10 \mathrm{mg} / \mathrm{kg} \text { vs. } \\
\text { placebo }\end{array}$ & 709 & $\begin{array}{l}\text { Significant improvement } \\
\text { in PFS and OS for patients } \\
\text { with durvalumab vs. with } \\
\text { placebo (PFS median } 17.2 \\
\text { vs. } 5.6 \text { mo; HR, } 0.51 \text {, } \\
P<0.001 \text {; HR for OS }=0.68 \text {, } \\
P=0,0025 \text { ); }\end{array}$ & $\begin{array}{l}\text { Response rate was } \\
28 \% \text { with durvalumab } \\
\text { vs. } 16 \% \text { with placebo }\end{array}$ & $\begin{array}{l}\text { PFS and OS benefits } \\
\text { with durvalumab } \\
\text { were observed in all } \\
\text { subgroups, including } \\
\text { PD-L1 expression } \\
\geq 25 \% \text { or }<25 \%\end{array}$ \\
\hline
\end{tabular}

Abbreviations: OS overall survival, NSCLC non-small cell lung cancer, Sq squamous, HR hazard ratio, ORR objective response rate, ITT Intent to treat, $P D-1$,

programmed cell death protein-1, PD-L1 programmed cell death ligand-1, PS proportion score

stage III NSCLC patients who did not have disease progression after two or more cycles of platinum-based chemoradiotherapy, durvalumab was found to have significantly better PFS, response rate, median time to death or distant metastasis, and OS when compared with placebo [8, 9], which led to FDA's approval of durvalumab for treatment of uresectable stage III NSCLC whose disease has not progressed following concurrent platinum-based chemotherapy 
and radiation therapy. The PFS and OS benefits with durvalumab were observed irrespective of PD-L1 expression before chemoradiotherapy based the stratification of PD-L1 $\geq$ $25 \%$ or $<25 \%$. In another trial (ATLANTIC) with 444 NSCLC patients enrolled in three cohorts, it was found that the proportion of patients with $\mathrm{EGFR}^{-} / \mathrm{ALK}^{-}$NSCLC achieving a response was higher than that with $\mathrm{EGFR}^{+}$/ $\mathrm{ALK}^{+}$NSCLC, nevertheless durvalumab activity was observed in patients with $\mathrm{EGFR}^{+}$NSCLC whose tumor has $\geq 25 \%$ PD-L1 expression [27].

\section{Predictive biomarkers associated with response to ICls}

Multiple biomarkers have emerged as being associated with treatment responses to immune checkpoint blockade therapies, including tumor mutational load [28, 29], DNA mismatch repair deficiency [30, 31], composition of gut microbiome [32,33], intensity of CD8+ cell infiltration [34] and intratumoral PD-L1 expression [35].

The presence of tumor-specific antigens and the interaction of immune cells with tumor antigens are the two basic principles of cancer immunology. Tumor antigens can derive from mutant proteins, overexpressed or dysregulated embryonic proteins, and oncogenic viral proteins. Increased nonsynonymous mutation burden in tumor tissues was expected to increase neoantigens in tumor, leading to stronger immune response against cancer cells. Indeed, clinical trials in lung cancer and melanoma have shown that high tumor mutation burden (TMB) was significantly associated with better objective response, durable clinical benefit, and prolonged progression-free survival for patients treated with ICIs $[28,29]$. Analysis on data of ICI therapy available in literature for 27 cancer types revealed a significant correlation between the TMB and the objective response rate of anti-PD-1/PD-L1 therapies [36]. In a randomized phase III trial with stage IV or recurrent NSCLC, nivolumab as first-line therapy was found not superior to chemotherapy in PFS or response rate in patients whose tumor had PD-L1 expression of $\geq 5 \%$. However, nivolumab was found to have higher response rate and longer PFS than chemotherapy among patients with high TMB [37]. Nevertheless, in another phase III trial with stage IV or recurrent NSCLC that was not previously treated with chemotherapy, no significant difference in PFS was found between nivolumab monotherapy and chemotherapy in patients with high TMB [38]. However, TMB was found to be strongly associated with efficacy of ICI combination therapy and was independent of PD-L1 expression [38, 39]. High TMB predicted better objective response, durable benefit and longer PFS in patients treated with nivolumab plus ipilimumab when compared with chemotherapy, of regardless PD-L1 expression. In patients with a low TMB, however, nivolumab plus ipilimumab didn't provide a benefit over chemotherapy, suggesting that ICI combination therapy alone is insufficient to overcome the resistance caused by low immunogenicity in tumors.

Lung cancer is known to have high TMB when compared with other cancers [40], presumably because lung is directly exposed to mutagens present in tobacco smoke. The average mutation frequency in lung cancer is more than 10-fold higher in smokers than in never-smokers [41]. In fact, molecular smoking signature is significantly associated with improved PFS in patients treated with pembrolizumab, although self-reported smoking history did not significantly associate with benefit of pembrolizumab treatment [28]. In addition to direct exposure to mutagens, driver mutations in genes involved in DNA replication and repair pathways drastically impact on the scale of mutation load [42]. For example, cancers with loss-of-function mutations in genes required for DNA mismatch repair, such as $M L H 1$, MSH2, MSH6, and PMS2, are known to have increased microsatellite instability and to have 100- to 600-fold increases in gene mutation rates [43, 44]. Most solid tumors contain, on average, 60 to 140 nonsynonymous mutations in their genome [40, 45], whereas cancers with mismatch repair deficiency contain, on average, 1400 to 1600 nonsynonymous mutations [31]. Tumors with DNA mismatch repair deficiencies showed greater densities of CD8+ tumor-infiltrating lymphocytes (TILs) and higher PD-L1 expression, and improved response rates and higher survival rates were achieved when patients with these tumors were treated with immune checkpoint inhibitors [30, 31]. DNA mismatch repair deficiency and/or microsatellite instability are detected in about $10 \%$ to $15 \%$ of colorectal, ovarian, gastric, and endometrial cancers [46-48]. Nevertheless, DNA mismatch repair deficiency or microsatellite instability is detected in less than $1 \%$ of NSCLC $[49,50]$.

High neoantigen burden in tumors are expected to trigger an anticancer immune response, recruiting immune cells to cancer sites and leading to increased levels of TILs, especially effector CD8+ T cells, and immune regulatory cells, such as helper $\mathrm{T}$ cells, Tregs, dendritic cells, and macrophages at the cancer site. Activation of $\mathrm{T}$ lymphocytes by tumor antigen ultimately leads to production and secretion of IFNy, a cytokine that stimulates TIL proliferation and differentiation, thereby enhancing TIL's effector functions. Paradoxically, IFNY also trigger TIL apoptosis by inducing PDL1 expression in the tumor microenvironment [51-53], which causes to a negative-feedback that eventually inhibits antitumor immunity.

PD-L1 is not expressed in most normal tissues. However, its expression can be induced by some cancer drivers $[54,55]$ or by IFN $\gamma[56,57]$. IFN $\gamma$-induced PD-L1 expression has a unique histopathological pattern, which is usually focal rather than diffuse and is expressed in cells 
adjacent to TILs, as observed in most human cancers [51, $58,59]$. Therefore, both increased TIL levels and increased expression of PD-L1 in the tumor tissues can serve as surrogate biomarkers of immunogenicity of cancer cells and interactions between cancer cells and immune cells or of the presence of adaptive immune resistance [58, 60, 61]. It has been proposed that, based on the presence or absence of PD-L1 expression and TILs, the tumor microenvironment can be classified into four groups [62, 63]: 1) TIL and PD-L1 double-positive, suggesting the presence of adaptive immune resistance; tumor will likely benefit from PD-L1/PD-1 blockade therapy; 2) TIL and PD-L1 double-negative, indicating immune ignorance or lack of detectable immune reaction; tumor will likely not to benefit from ICI therapy; 3) TIL-negative but PD-L1-positive; indicating that PD-L1 expression in cancers is independent of IFN $\gamma$ but is intrinsic through oncogenic signaling; tumor may not respond to immune checkpoint inhibitors; and 4) TIL-positive but PD-L1-negative, indicating that other immune-suppressive mechanisms may mediate immune tolerance; targeting alternative immune suppressive pathways will be required to restore anticancer immunity.

This classification of the tumor microenvironment provides some insight to the discordant results observed in clinics and suggests that PD-L1 expression alone may not completely predict the response to immune checkpoint blockade therapy. Higher levels of PD-L1 expression in tumor tissues were found to have significantly better response rates and better survival in some ICI clinical trials, such as KEYNOTE-001 [5], CheckMate 057 [3], and POPLAR [23]. However, expression of PD-L1 was neither prognostic nor predictive of clinic benefit in CheckMate 017 [4]. In addition, intratumoral heterogeneity of neoantigens [64], different methods (distinct immunohistochemistry antibody clones, staining methods, and scoring systems), and different cutoff values in clinical evaluation of PD-L1 may have also led to discordant results [65].

\section{Lymphocytes reactive to neoantigens}

Evidence has shown that intensive lymphocytes infiltrations in tumor stroma and/or intraepithelial tumor nest are associated with better prognosis in lung cancer [66-69]. For example, a study with more than 1500 cases of resectable NSCLC patients has showed that about 10\% of NSCLC patients had intense lymphocytic infiltration in their tumors and this subset of patients had improved overall survival than the patients with nonintense tumor lymphocyte infiltration [68]. In particular, high density of $\mathrm{CD}^{+}$and/or $\mathrm{CD} 4^{+} \mathrm{T}$ cells in tumor stroma were independent favorable prognostic factors for NSCLC $[66,67,69]$. More recently, it has been shown that a subset of memory $\mathrm{T}$ cells, designated as tissue resident memory $\mathrm{T}$ cells $\left(\mathrm{T}_{\mathrm{RM}}\right)$, resident in tissues and do not recirculate via bloodstream. The majority of these $\mathrm{T}_{\mathrm{RM}}$ cells express CD69 and CD103. Higher density of $T_{R M}$ cells in tumors was recently reported to be predictive of a better survival outcome in lung cancer [70-72]. $\mathrm{CD}^{+} \mathrm{CD} 103^{+} \mathrm{TIL}$ freshly isolated from NSCLC specimens often express both PD-1 and TIM-3. This TIL subset is found to have increased activation-induced cell death and is capable of mediating specific cytolytic activity against autologous tumor cells when PD-1/PDL1 interaction was blocked [70, 71].

Evidence has shown that naïve $\mathrm{T}$ cells are more effective than memory $\mathrm{T}$ cells and that central memory $\mathrm{T}$ cells $\left(\mathrm{T}_{\mathrm{CM}}\right)$ are more effective than effector memory $\mathrm{T}$ cells $\left(\mathrm{T}_{\mathrm{EM}}\right)$ in adoptive cellular therapy for cancers [73-75]. Analysis on a subpopulation of TILs in melanoma showed that tumor-reactive $\mathrm{CD}^{+} \mathrm{T}$ cells were largely derived from $\mathrm{CD} 8^{+} \mathrm{PD}-1^{+} \mathrm{T}$ cells, even though the level of PD-1 expression on $\mathrm{CD}^{+}$tumor-specific TILs decreased during culture with IL-2 [76, 77]. PD-1 overexpression is frequently detected in $\mathrm{CD}^{+} \mathrm{T}$ cells freshly isolated from melanoma, followed by TIM-3, 4-1BB, and LAG-3 [77]. Moreover substantial coexpression of these four receptors was detected on a subset of $\mathrm{CD} 8^{+}$TILs. Expression of TIM-3, LAG-3, and 4-1BB was almost exclusively present on $\mathrm{PD}-1^{+}$cells. Up-regulation of multiple inhibitory receptors in CD8+ cells was observed in chronic antigen stimulation, including chronical infection, and is known to be associated with T-cell exhaustion $[78,79]$. Interestingly, $\mathrm{CD} 8^{+} \mathrm{PD}-1^{+} \mathrm{T}$ cells isolated from the peripheral blood of melanoma patients are also neoantigen-reactive [80]. Tumor antigen (including mutated neoantigens, cancer germline antigens, and viral antigens)-specific $\mathrm{T}$ cells can be obtained from both tumor tissues and autologous peripheral blood from $\mathrm{CD} 8^{+} \mathrm{PD}-1^{+}$cell populations (at frequencies of about $0.4-0.002 \%$ in blood) [80-82]. The tumor antigen-specific $\mathrm{CD} 4^{+}$or $\mathrm{CD} 8^{+}$TILs targeting mutant ERBB2IP and KRAS have been shown to have high anticancer activity in patients [83, 84]. Of interest, the tumor-antigen specificities and TCR repertoires of the $\mathrm{CD} 8^{+} \mathrm{PD}-1^{+}$cells from peripheral blood and tumor tissues are similar [80], suggesting that the circulating $\mathrm{CD} 8^{+} \mathrm{PD}-1^{+} \mathrm{T}$ cells might be a novel noninvasive approach of adoptive cell therapy with neoantigen-reactive lymphocytes, or serve as a surrogate biomarker for adaptive immune resistance.

\section{Resistance to immune checkpoint inhibitors}

The mechanisms of resistance to immune checkpoint blockade therapy are not yet well characterized but likely involve multiple factors. A recent study showed that abnormal gut microbiome composition due to the use of antibiotics before immune therapy inhibited the clinical benefit of immune checkpoint blockade therapy in cancer patients [33]. Several oncogenes and tumor suppressor 
genes have been reported to affect efficacy of ICI therapy [85-87]. Also, the presence of parallel immune inhibitory pathways and the loss of antigen presentation in cancer cells can be a common mechanism of resistance.

Activating mutations in the EGFR gene are found in approximately $10-17 \%$ of lung adenocarcinoma in Caucasians and in approximately $30-65 \%$ of lung adenocarcinoma patients in Asia [88]. Clinical trials with nivolumab [3], pembrolizumab [21], atezolizumab [7], and durvalumab [8] showed no significant survival benefit in EGFR-mutant patients treated with these ICIs. A meta-analysis on data from randomized trials of ICIs in NSCLC also found that no significant improvement in OS in the EGFR mutant subgroup treated with ICIs, although prolonged OS was observed in whole study populations and in the EGFR wild-type subgroup when compared with patients treated with docetaxel [86]. It is not clear whether the EGFR-mutant cancers have lower TMB than EGFR-wild type tumors. Intriguingly, treatment with ICIs was found to result in accelerated tumor growth and clinical deterioration in a subset of patients when compared with pretherapy. Genomic alterations in the $M D M 2 / M D M 4$ and EGFR genes were found to be correlated with this "hyperprogressor" phenotype [87]. Genomic alterations in the STK11 gene are another factor reported to cause ICI resistance in NSCLC [85]. In lung adenocarcinoma patients with KRAS mutations, co-mutations in STK11 were associated with inferior clinical outcome following PD-1 blockade therapy. STK11 mutations is significantly enriched among tumors with intermediate/high TMB and negative PD-L1 expression. Moreover, knockout of Stk11 resulted in resistance to PD-1 blockade therapy in a Kras-mutant syngeneic mouse model [85], demonstrating STK11 mutations are a causal factor of resistance to ICIs.

Presence of parallel immune inhibitory pathways has been extensively investigated as the causal factors in ICI resistance. For example, indoleamine-2,3-dioxygenase (IDO), a metabolic enzyme that catalyzes the rate-limiting step of tryptophan degradation, has been reported to play a critical role in resistance to immunotherapy targeting CTLA-4 [89]. Induced by inflammatory signals such as prostaglandins, IFN $\gamma$, and tumor necrosis factor alpha (TNF- $\alpha$ ) [90], IDO functions as a key mediator in activating and maintaining the immune suppressive function of Treg cells [91]. Coexpression of multiple T-cell inhibitory receptors (TCIRs), including PD-1, CTLA4, TIM3, and LAG3, in activated and/or exhausted T cells, suggested that parallel inhibitory pathways may mediate resistance to ICI therapy targeting a single TCIR and that simultaneous inhibition of multiple TCIRs may be required to improve therapeutic efficacy. Upregulation of TIM3 was found in PD-1 antibody bound T cells in both murine models of lung adenocarcinoma and in lung cancer patients with adaptive resistance to anti-PD-1 therapy [92]. Sequential PD-1 and TIM3 blockade prolonged survival in a mouse tumor model, indicating potential benefit of anti-PD-1 and anti-TIM3 combination therapy. Prolonged interferon signaling was reported to augment expression of interferon-stimulated genes, including multiple TCIRs and their ligands, leading to resistance to the ICI [93]. Impaired human leukocyte antigen (HLA) class I antigen processing and presentation due to homologous loss or down-regulation of B2M has also been found as a mechanism of acquired resistance to ICIs in lung cancer patients [94, 95]. CRISPR-mediated knock-out of $B 2 m$ in an immunocompetent lung cancer mouse model conferred resistance to PD-1 blockade in vivo [94], demonstrating the causal relationship between loss of B2m and resistance to ICIs.

Because ICIs primarily target the immunosuppressive signals at cancer sites by locoregional blockade of negative feedbacks induced by inhibitory receptors [59], the absence of CTLs at tumor tissues, as observed in most cancer patients $[58,63]$, could be a major barriers for ICI therapy [35, 59]. In contrast, inflammatory signals are known to strongly augment activated T-cell homing to region of infection $[96,97]$. It has been reported that presence of local infection and/or expression of foreign genes, $T$ cell activations were induced by even very weak interactions between T-cell receptors and their ligands, resulting in rapid proliferation and amplification of immune effector and memory cells [98]. Thus, we hypothesized that resistance to ICI therapy caused by low immunogenicity of cancer cells or lack of immune cell infiltration at cancer sites might be overcome by inducing lymphocyte infiltration at cancer sites through installation of locoregional inflammatory signals.

To test this hypothesis, we investigated the effects of anti-PD therapy in combination with locoregional adenovirotherapy in the syngeneic lung cancer model M109. We found that the M109 tumor does not express PD-L1, does not have $\mathrm{CD}^{+}$or $\mathrm{CD}_{4}^{+}$lymphocyte infiltration in cancer tissues, and is resistant to both anti-PD-1 and anti-PD-L1 treatments. Intratumoral administration of an oncolytic adenovirus led to dramatic intratumoral infiltration of both $\mathrm{CD}_{4}^{+}$and $\mathrm{CD} 8^{+}$lymphocytes and sensitized the M109 tumor to the treatment of anti-PD-1 or anti-PD-L1 antibodies [99]. This result provided a proof-of-concept evidence that resistance ICIs in lung cancer can be overcome by locoregional virotherapies. A similar result was observed in a clinical trial of combination therapy of pembrolizumab with talimogene laherparepvec, a modified herpes simplex virus type 1 that selectively replicates in tumors and expresses granulocyte-macrophage colony-stimulating factor (GM-CSF), in patients with advanced melanoma [100]. IFN $\gamma$ gene expression in tumor cells after talimogene laherparepvec treatment, increased $\mathrm{CD}^{+} \mathrm{T}$ cells and elevated PD-L1 protein expression were 
detected in cancers of the patients who responded to the combination therapy. In addition, baseline $\mathrm{CD} 8^{+} \mathrm{T}$-cell infiltration or baseline IFN $\gamma$ signature were not associated with the response to the combination therapy, suggesting that locoregional virotherapy may overcome primary resistance to ICI therapy by modulating the tumor immune microenvironment.

Promoting lymphocyte infiltration in tumors by other approaches, such as by targeted delivery of LIGHT (TNFSF14) gene to the tumor [101] or by targeted type I IFN activation through peritumoral injections of immunostimulatory RNA (poly:IC) [102], has also been shown to overcome resistance to anti-PD-1 and/or anti-PD-L1 therapies, demonstrating that the presence of lymphocytes at cancer sites is the basis for effective immunotherapy with ICIs.

\section{Future prospects}

Currently, the testing of PDL1 expression in the tumor microenvironment [5] and testing for the presence of mismatched repair deficiency in tumor cells [103], which correlates with microsatellite instability and tumor mutational burden, have been approved by the FDA for guidance of ICI therapy in clinics. However, PDL1 expression is often highly heterogeneous within a tumor and often in disagreement between the primary tumor and the metastatic lesions [104-106], which poses a challenge in using the information obtained from analysis of single small biopsy samples in clinical practice. Knowledge gained from adoptive cell therapy might provide some new ideas in searching for novel predictive biomarkers. For example, it might be interesting to determine whether levels or dynamic changes of CD8 ${ }^{+}$PD- $1^{+} \mathrm{T}$ cells in peripheral blood $[80,107]$ are associated with treatment responses to ICIs.

Identification of new therapeutic targets and/or development of new therapeutic agents that modulate immune responses will broaden the applications of immunotherapy for cancers. Similarly, strategies that enhance immunogenicity of tumor cells or attract immune cells to cancer sites are expected to be effective approaches to overcoming primary resistance. Indeed, locoregional oncolytic virotherapy has been shown to sensitize tumors resistant to anti-PD-1 or anti-PD-L1 therapy preclinically and clinically $[99,100]$, presumably because locoregional inflammatory signals promote lymphocyte infiltration at cancer sites. Therapeutic approaches that induce immunogenicity of cancer cells, such as inducing immunogenic cell death [108] by radiotherapy $[109,110]$, chemotherapy [111], or chemoradiotherapy [112], are also expected to attract lymphocytes to cancer sites, thereby sensitizing tumors to ICI therapy. Therefore, combining ICIs with therapies that promote immunogenicity in tumors or attract lymphocytes to cancer sites will likely be further pursued both preclinically and clinically. A recent phase III trial in patients with previously untreated metastatic nonsquamous NSLCL without EGFR or ALK mutations showed that standard chemotherapy plus pembrolizumab resulted in significantly longer OS and PFS than chemotherapy alone [113]. The benefit of adding pembrolizumab was observed in all subgroups, including those with PD-L1 expression of $<1 \%$, demonstrating feasibility of enhancing immunogenicity in tumors via chemotherapy. On the other hand, loss of antigen presentation caused by genetic alterations in genes involved antigen presentations, such as B2M [94] and HLA [84], has been reported in acquired resistance to anticancer immune therapy. Overcoming the resistance caused by a loss of antigen presentation may require strategies that eliminate cancers independent of HLA, such as adoptive cell therapy with NK cells or chimeric antigen receptor $\mathrm{T}$ cells. Progress has also been made in the field of adoptive cellular therapy [114]. The knowledge gained from both ICIs and adoptive cell therapy is expected to have a tremendous impact on the clinical practice of immunotherapy for lung cancer.

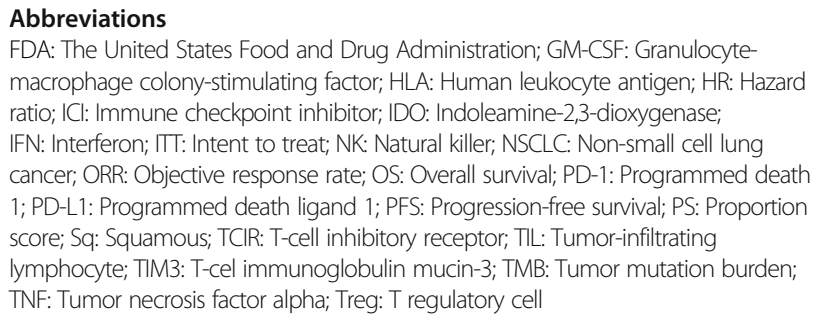

\section{Acknowledgments}

We thank Tamara K. Locke and the Department of Scientific Publications at The University of Texas MD Anderson Cancer Center for editorial review of the manuscript.

\section{Funding}

This work was supported by National Institutes of Health/National Cancer Institute grantR01CA190628 and by endowed funds to The University of Texas MD Anderson Cancer Center, including the Sister Institution Network Fund.

Availability of data and materials

The data cited in this manuscript can be found in the cited articles.

Authors' contributions

$\mathrm{XP}$ and $\mathrm{BF}$ conceived the project. XP, LW, DS, WM, and BF collected references and wrote the manuscript. All authors read and approved the final manuscript.

Ethics approval and consent to participate Not applicable.

\section{Consent for publication}

Not applicable.

\section{Competing interests}

The authors declare that they have no competing interests.

\section{Publisher's Note}

Springer Nature remains neutral with regard to jurisdictional claims in published maps and institutional affiliations. 


\section{Author details}

'Department of Thoracic and Cardiovascular Surgery, The University of Texas MD Anderson Cancer Center, Houston, TX 77030, USA. ²Department of Thoracic Medical Oncology, Hunan Cancer Hospital/the affiliated Cancer Hospital of Xiangya school of Medicine, Central South University, 283 Tongzipo Road, Yuelu District, Changsha 410013, Hunan, China. ${ }^{3}$ Department of Pathology, Zhejiang Cancer Hospital, 38 Guanji Road, Banshan Bridge, Hangzhou 310022, Zejiang, China. ${ }^{4}$ Department of Thoracic Surgery, Zhejiang Cancer Hospital, 38 Guanji Road, Banshan Bridge, Hangzhou 310022, Zejiang, China.

Received: 3 September 2018 Accepted: 24 October 2018

Published online: 08 November 2018

\section{References}

1. Siegel RL, Miller KD, Jemal A. Cancer statistics, 2017. CA Cancer J Clin. 2017; 67(1):7-30.

2. Torre LA, Bray F, Siegel RL, Ferlay J, Lortet-Tieulent J, Jemal A. Global cancer statistics, 2012. CA Cancer J Clin. 2015;65(2):87-108.

3. Borghaei H, Paz-Ares L, Horn L, Spigel DR, Steins M, Ready NE, Chow LQ, Vokes EE, Felip E, Holgado E, et al. Nivolumab versus docetaxel in advanced nonsquamous non-small-cell lung Cancer. N Engl J Med. 2015;373(17):1627-39.

4. Brahmer J, Reckamp KL, Baas P, Crino L, Eberhardt WE, Poddubskaya E, Antonia S, Pluzanski A, Vokes EE, Holgado E, et al. Nivolumab versus docetaxel in advanced squamous-cell non-small-cell lung Cancer. N Engl J Med. 2015;373(2):123-35.

5. Garon EB, Rizvi NA, Hui R, Leighl N, Balmanoukian AS, Eder JP, Patnaik A, Aggarwal C, Gubens M, Horn L, et al. Pembrolizumab for the treatment of non-small-cell lung cancer. N Engl J Med. 2015;372(21):2018-28.

6. Goldberg SB, Gettinger SN, Mahajan A, Chiang AC, Herbst RS, Sznol M, Tsiouris AJ, Cohen J, Vortmeyer A, Jilaveanu L, et al. Pembrolizumab for patients with melanoma or non-small-cell lung cancer and untreated brain metastases: early analysis of a non-randomised, open-label, phase 2 trial. Lancet Oncol. 2016;17(7):976-83.

7. Rittmeyer A, Barlesi F, Waterkamp D, Park K, Ciardiello F, von Pawel J, Gadgeel SM, Hida T, Kowalski DM, Dols MC, et al. Atezolizumab versus docetaxel in patients with previously treated non-small-cell lung cancer (OAK): a phase 3, open-label, multicentre randomised controlled trial. Lancet. 2017;389(10066):255-65.

8. Antonia SJ, Villegas A, Daniel D, Vicente D, Murakami S, Hui R, Yokoi T, Chiappori A, Lee KH, de Wit M, et al. Durvalumab after Chemoradiotherapy in stage III non-small-cell lung Cancer. N Engl J Med. 2017;377(20):1919-29.

9. Antonia SJ, Villegas A, Daniel D, Vicente D, Murakami S, Hui R, Kurata T, Chiappori A, Lee KH, de Wit M, et al. Overall survival with Durvalumab after Chemoradiotherapy in stage III NSCLC. N Engl J Med. 2018. https://doi.org/ 10.1056/NEJMoa1809697 [Epub ahead of print].

10. Kazandjian D, Suzman DL, Blumenthal G, Mushti S, He K, Libeg M, Keegan P, Pazdur R. FDA approval summary: Nivolumab for the treatment of metastatic non-small cell lung Cancer with progression on or after platinum-based chemotherapy. Oncologist. 2016;21(5):634-42.

11. Weinstock C, Khozin S, Suzman D, Zhang L, Tang S, Wahby S, Goldberg KB, Kim G, Pazdur R. U.S. Food and Drug Administration approval summary: Atezolizumab for metastatic non-small cell lung Cancer. Clin Cancer Res. 2017;23(16):4534-9.

12. Sul J, Blumenthal GM, Jiang X, He K, Keegan P, Pazdur R. FDA approval summary: Pembrolizumab for the treatment of patients with metastatic non-small cell lung Cancer whose tumors express programmed deathligand 1. Oncologist. 2016;21(5):643-50.

13. Pai-Scherf L, Blumenthal GM, Li H, Subramaniam S, Mishra-Kalyani PS, He K, Zhao H, Yu J, Paciga M, Goldberg KB, et al. FDA approval summary: Pembrolizumab for treatment of metastatic non-small cell lung Cancer: firstline therapy and beyond. Oncologist. 2017. https://doi.org/10.1634/ theoncologist.2017-0078.

14. Ettinger DS, Wood DE, Aisner DL, Akerley W, Bauman J, Chirieac LR, D'Amico TA, DeCamp MM, Dilling TJ, Dobelbower M, et al. Non-small cell lung Cancer, version 5.2017, NCCN clinical practice guidelines in oncology. J Natl Compr Cancer Netw. 2017;15(4):504-35.

15. Gulley JL, Rajan A, Spigel DR, lannotti N, Chandler J, Wong DJL, Leach J, Edenfield WJ, Wang D, Grote HJ, et al. Avelumab for patients with previously treated metastatic or recurrent non-small-cell lung cancer
(JAVELIN solid tumor): dose-expansion cohort of a multicentre, open-label, phase 1b trial. Lancet Oncol. 2017;18(5):599-610.

16. Brahmer JR, Drake CG, Wollner I, Powderly JD, Picus J, Sharfman WH, Stankevich E, Pons A, Salay TM, McMiller TL, et al. Phase I study of singleagent anti-programmed death-1 (MDX-1106) in refractory solid tumors: safety, clinical activity, pharmacodynamics, and immunologic correlates. J Clin Oncol. 2010;28(19):3167-75.

17. Davies AM, Rispens T, Ooijevaar-de Heer P, Gould HJ, Jefferis R, Aalberse RC, Sutton BJ. Structural determinants of unique properties of human lgG4-fc. J Mol Biol. 2014;426(3):630-44.

18. Gettinger SN, Horn L, Gandhi L, Spigel DR, Antonia SJ, Rizvi NA, Powderly JD, Heist RS, Carvajal RD, Jackman DM, et al. Overall survival and long-term safety of Nivolumab (anti-programmed death 1 antibody, BMS-936558, ONO-4538) in patients with previously treated advanced non-small-cell lung Cancer. J Clin Oncol. 2015;33(18):2004-12.

19. Topalian SL, Hodi FS, Brahmer JR, Gettinger SN, Smith DC, McDermott DF, Powderly JD, Carvajal RD, Sosman JA, Atkins MB, et al. Safety, activity, and immune correlates of anti-PD-1 antibody in cancer. N Engl J Med. 2012; 366(26):2443-54.

20. Rizvi NA, Mazieres J, Planchard D, Stinchcombe TE, Dy GK, Antonia SJ, Horn $\mathrm{L}$, Lena $\mathrm{H}$, Minenza $\mathrm{E}$, Mennecier $\mathrm{B}$, et al. Activity and safety of nivolumab, an anti-PD-1 immune checkpoint inhibitor, for patients with advanced, refractory squamous non-small-cell lung cancer (CheckMate 063): a phase 2 , single-arm trial. Lancet Oncol. 2015;16(3):257-65.

21. Herbst RS, Baas P, Kim DW, Felip E, Perez-Gracia JL, Han JY, Molina J, Kim JH, Arvis CD, Ahn MJ, et al. Pembrolizumab versus docetaxel for previously treated, PD-L1-positive, advanced non-small-cell lung cancer (KEYNOTE-010): a randomised controlled trial. Lancet. 2016;387(10027):1540-50.

22. Reck M, Rodriguez-Abreu D, Robinson AG, Hui R, Csoszi T, Fulop A, Gottfried M, Peled N, Tafreshi A, Cuffe S, et al. Pembrolizumab versus chemotherapy for PD-L1-positive non-small-cell lung Cancer. N Engl J Med. 2016;375(19): 1823-33.

23. Fehrenbacher L, Spira A, Ballinger M, Kowanetz M, Vansteenkiste J, Mazieres J, Park K, Smith D, Artal-Cortes A, Lewanski C, et al. Atezolizumab versus docetaxel for patients with previously treated non-small-cell lung cancer (POPLAR): a multicentre, open-label, phase 2 randomised controlled trial. Lancet. 2016;387(10030):1837-46.

24. Stewart R, Morrow M, Hammond SA, Mulgrew K, Marcus D, Poon E, Watkins A, Mullins S, Chodorge M, Andrews J, et al. Identification and characterization of MEDI4736, an antagonistic anti-PD-L1 monoclonal antibody. Cancer Immunol Res. 2015;3(9):1052-62.

25. Oganesyan V, Gao C, Shirinian L, Wu H, Dall'Acqua WF. Structural characterization of a human fc fragment engineered for lack of effector functions. Acta Crystallogr D Biol Crystallogr. 2008;64(Pt 6):700-4.

26. Powles T, O'Donnell PH, Massard C, Arkenau HT, Friedlander TW, Hoimes CJ, Lee $J$, Ong M, Sridhar SS, Vogelzang NJ, et al. Efficacy and safety of Durvalumab in locally advanced or metastatic urothelial carcinoma: updated results from a phase 1/2 open-label study. JAMA Oncol. 2017;3(9):e172411.

27. Garassino MC, Cho BC, Kim JH, Mazieres J, Vansteenkiste J, Lena H, Corral Jaime J, Gray JE, Powderly J, Chouaid C, et al. Durvalumab as third-line or later treatment for advanced non-small-cell lung cancer (ATLANTIC): an open-label, single-arm, phase 2 study. Lancet Oncol. 2018;19(4):521-36.

28. Rizvi NA, Hellmann MD, Snyder A, Kvistborg P, Makarov V, Havel JJ, Lee W, Yuan J, Wong P, Ho TS, et al. Cancer immunology. Mutational landscape determines sensitivity to PD-1 blockade in non-small cell lung cancer. Science. 2015;348(6230):124-8.

29. Snyder A, Makarov V, Merghoub T, Yuan J, Zaretsky JM, Desrichard A, Walsh LA, Postow MA, Wong P, Ho TS, et al. Genetic basis for clinical response to CTLA-4 blockade in melanoma. N Engl J Med. 2014;371(23):2189-99.

30. Le DT, Uram JN, Wang H, Bartlett BR, Kemberling H, Eyring AD, Skora AD, Luber BS, Azad NS, Laheru D, et al. PD-1 blockade in tumors with mismatchrepair deficiency. N Engl J Med. 2015;372(26):2509-20.

31. Le DT, Durham JN, Smith KN, Wang H, Bartlett BR, Aulakh LK, Lu S, Kemberling $\mathrm{H}$, Wilt $\mathrm{C}$, Luber BS, et al. Mismatch repair deficiency predicts response of solid tumors to PD-1 blockade. Science. 2017;357(6349):409-13.

32. Gopalakrishnan V, Spencer CN, Nezi L, Reuben A, Andrews MC, Karpinets TV, Prieto PA, Vicente D, Hoffman K, Wei SC, et al. Gut microbiome modulates response to anti-PD-1 immunotherapy in melanoma patients. Science. 2018; 359(6371):97-103.

33. Routy B, Le Chatelier E, Derosa L, Duong CPM, Alou MT, Daillere R, Fluckiger A, Messaoudene M, Rauber C, Roberti MP, et al. Gut 
microbiome influences efficacy of PD-1-based immunotherapy against epithelial tumors. Science. 2018;359(6371):91-97.

34. Tumeh PC, Harview CL, Yearley JH, Shintaku IP, Taylor EJ, Robert L, Chmielowski B, Spasic M, Henry G, Ciobanu V, et al. PD-1 blockade induces responses by inhibiting adaptive immune resistance. Nature. 2014;515(7528): 568-71.

35. Herbst RS, Soria JC, Kowanetz M, Fine GD, Hamid O, Gordon MS, Sosman JA, McDermott DF, Powderly JD, Gettinger SN, et al. Predictive correlates of response to the anti-PD-L1 antibody MPDL3280A in cancer patients. Nature. 2014;515(7528):563-7.

36. Yarchoan M, Hopkins A, Jaffee EM. Tumor mutational burden and response rate to PD-1 inhibition. N Engl J Med. 2017;377(25):2500-1.

37. Carbone DP, Reck M, Paz-Ares L, Creelan B, Horn L, Steins M, Felip E, van den Heuvel MM, Ciuleanu TE, Badin F, et al. First-line Nivolumab in stage IV or recurrent non-small-cell lung Cancer. N Engl J Med. 2017; 376(25):2415-26.

38. Hellmann MD, Ciuleanu TE, Pluzanski A, Lee JS, Otterson GA, AudigierValette C, Minenza E, Linardou H, Burgers S, Salman P, et al. Nivolumab plus Ipilimumab in lung Cancer with a high tumor mutational burden. N Engl J Med. 2018;378(22):2093-104.

39. Hellmann MD, Nathanson T, Rizvi H, Creelan BC, Sanchez-Vega F, Ahuja A, $\mathrm{Ni} A$, Novik JB, Mangarin LMB, Abu-Akeel M, et al. Genomic Features of Response to Combination Immunotherapy in Patients with Advanced NonSmall-Cell Lung Cancer. Cancer Cell. 2018;33(5):843-852.e844.

40. Vogelstein B, Papadopoulos N, Velculescu VE, Zhou S, Diaz LA Jr, Kinzler KW. Cancer genome landscapes. Science. 2013;339(6127):1546-58.

41. Gottlieb NL. Pharmacology of auranofin: overview and update. Scand J Rheumatol Suppl. 1986;63:19-28.

42. Campbell BB, Light N, Fabrizio D, Zatzman M, Fuligni F, de Borja R, Davidson S, Edwards M, Elvin JA, Hodel KP, et al. Comprehensive Analysis of Hypermutation in Human Cancer. Cell. 2017;171(5):1042-1056.e1010.

43. Parsons R, Li GM, Longley MJ, Fang WH, Papadopoulos N, Jen J, de la Chapelle A, Kinzler KW, Vogelstein B, Modrich P. Hypermutability and mismatch repair deficiency in RER+ tumor cells. Cell. 1993;75(6):1227-36.

44. Bhattacharyya NP, Skandalis A, Ganesh A, Groden J, Meuth M. Mutator phenotypes in human colorectal carcinoma cell lines. Proc Natl Acad Sci U S A. 1994;91(14):6319-23.

45. Kandoth C, McLellan MD, Vandin F, Ye K, Niu B, Lu C, Xie M, Zhang Q, McMichael JF, Wyczalkowski MA, et al. Mutational landscape and significance across 12 major cancer types. Nature. 2013;502(7471):333-9.

46. Shah SN, Hile SE, Eckert KA. Defective mismatch repair, microsatellite mutation bias, and variability in clinical cancer phenotypes. Cancer Res. 2010;70(2):431-5.

47. Murphy MA, Wentzensen N. Frequency of mismatch repair deficiency in ovarian cancer: a systematic review. Int J Cancer. 2011;129(8):1914-22.

48. Simpson AJ, Caballero OL, Pena SD. Microsatellite instability as a tool for the classification of gastric cancer. Trends Mol Med. 2001;7(2):76-80.

49. Takamochi K, Takahashi F, Suehara Y, Sato E, Kohsaka S, Hayashi T, Kitano S, Uneno T, Kojima S, Takeuchi K, et al. DNA mismatch repair deficiency in surgically resected lung adenocarcinoma: microsatellite instability analysis using the Promega panel. Lung Cancer. 2017;110:26-31.

50. Warth A, Korner S, Penzel R, Muley T, Dienemann H, Schirmacher P, von Knebel-Doeberitz M, Weichert W, Kloor M. Microsatellite instability in pulmonary adenocarcinomas: a comprehensive study of 480 cases. Virchows Arch. 2016;468(3):313-9.

51. Dong H, Strome SE, Salomao DR, Tamura H, Hirano F, Flies DB, Roche PC, Lu J, Zhu G, Tamada K, et al. Tumor-associated B7-H1 promotes T-cell apoptosis: a potential mechanism of immune evasion. [Erratum appears in Nat Med 2002 Sep.8(9):1039]. Nat Med. 2002;8(8):793-800.

52. Spranger S, Spaapen RM, Zha Y, Williams J, Meng Y, Ha TT, Gajewski TF. Upregulation of PD-L1, IDO, and T(regs) in the melanoma tumor microenvironment is driven by CD8(+) T cells. Sci Transl Med. 2013;5(200): 200ra116.

53. Schalper KA, Carvajal-Hausdorf D, McLaughlin J, Altan M, Velcheti V, Gaule P, Sanmamed MF, Chen L, Herbst RS, Rimm DL. Differential expression and significance of PD-L1, IDO-1, and B7-H4 in human lung Cancer. Clin Cancer Res. 2017;23(2):370-8.

54. Akbay EA, Koyama S, Carretero J, Altabef A, Tchaicha JH, Christensen CL Mikse OR, Cherniack AD, Beauchamp EM, Pugh TJ, et al. Activation of the PD-1 pathway contributes to immune escape in EGFR-driven lung tumors. Cancer Discov. 2013;3(12):1355-63.
55. Xu C, Fillmore CM, Koyama S, Wu H, Zhao Y, Chen Z, Herter-Sprie GS, Akbay EA, Tchaicha JH, Altabef A, et al. Loss of Lkb1 and Pten leads to lung squamous cell carcinoma with elevated PD-L1 expression. Cancer Cell. 2014; 25(5):590-604.

56. Muhlbauer M, Fleck M, Schutz C, Weiss T, Froh M, Blank C, Scholmerich J, Hellerbrand C. PD-L1 is induced in hepatocytes by viral infection and by interferon-alpha and -gamma and mediates T cell apoptosis. J Hepatol. 2006:45(4):520-8.

57. Lee SJ, Jang BC, Lee SW, Yang YI, Suh SI, Park YM, Oh S, Shin JG, Yao S, Chen $\mathrm{L}$, et al. Interferon regulatory factor- 1 is prerequisite to the constitutive expression and IFN-gamma-induced upregulation of B7-H1 (CD274). FEBS Lett. 2006;580(3):755-62.

58. Taube JM, Anders RA, Young GD, Xu H, Sharma R, McMiller TL, Chen S, Klein AP, Pardoll DM, Topalian SL, et al. Colocalization of inflammatory response with B7-h1 expression in human melanocytic lesions supports an adaptive resistance mechanism of immune escape. Sci Transl Med. 2012;4(127):127ra137.

59. Chen L, Han X. Anti-PD-1/PD-L1 therapy of human cancer: past, present and future. J Clin Invest. 2015;125(9):3384-91.

60. Yao $\mathrm{S}$, Chen L. Adaptive resistance: a tumor strategy to evade immune attack. Eur J Immunol. 2013;43(3):576-9.

61. Ribas A, Ribas A. Adaptive immune resistance: how Cancer protects from immune attack. Cancer Discov. 2015;5(9):915-9.

62. Sznol M, Chen L. Antagonist antibodies to PD-1 and B7-H1 (PD-L1) in the treatment of advanced human cancer. Clin Cancer Res. 2013;19(5):1021-34.

63. Teng MW, Ngiow SF, Ribas A, Smyth MJ. Classifying cancers based on T-cell infiltration and PD-L1. Cancer Res. 2015;75(11):2139-45.

64. McGranahan N, Furness AJ, Rosenthal R, Ramskov S, Lyngaa R, Saini SK, Jamal-Hanjani M, Wilson GA, Birkbak NJ, Hiley CT, et al. Clonal neoantigens elicit T cell immunoreactivity and sensitivity to immune checkpoint blockade. Science. 2016;351(6280):1463-9.

65. Schvartsman G, Ferrarotto R, Massarelli E. Checkpoint inhibitors in lung cancer: latest developments and clinical potential. Ther Advn Med Oncol. 2016;8(6):460-73.

66. Al-Shibli Kl, Donnem T, Al-Saad S, Persson M, Bremnes RM, Busund LT. Prognostic effect of epithelial and stromal lymphocyte infiltration in nonsmall cell lung cancer. Clin Cancer Res. 2008;14(16):5220-7.

67. Kawai O, Ishii G, Kubota K, Murata Y, Naito Y, Mizuno T, Aokage K, Saijo N, Nishiwaki Y, Gemma A, et al. Predominant infiltration of macrophages and CD8(+) T cells in cancer nests is a significant predictor of survival in stage IV nonsmall cell lung cancer. Cancer. 2008;113(6):1387-95.

68. Brambilla E, Le Teuff G, Marguet S, Lantuejoul S, Dunant A, Graziano S, Pirker R, Douillard JY, Le Chevalier T, Filipits M, et al. Prognostic effect of tumor lymphocytic infiltration in Resectable non-small-cell lung Cancer. J Clin Oncol. 2016;34(11):1223-30.

69. Geng Y, Shao Y, He W, Hu W, Xu Y, Chen J, Wu C, Jiang J. Prognostic role of tumor-infiltrating lymphocytes in lung Cancer: a meta-analysis. Cell Physiol Biochem. 2015;37(4):1560-71.

70. Djenidi F, Adam J, Goubar A, Durgeau A, Meurice G, de Montpreville V, Validire P, Besse B, Mami-Chouaib F. CD8+CD103+ tumor-infiltrating lymphocytes are tumor-specific tissue-resident memory $T$ cells and a prognostic factor for survival in lung cancer patients. J Immunol. 2015; 194(7):3475-86.

71. Ganesan AP, Clarke J, Wood O, Garrido-Martin EM, Chee SJ, Mellows T, Samaniego-Castruita D, Singh D, Seumois G, Alzetani A, et al. Tissue-resident memory features are linked to the magnitude of cytotoxic $T$ cell responses in human lung cancer. Nat Immunol. 2017;18(8):940-50.

72. Koh J, Kim S, Kim MY, Go H, Jeon YK, Chung DH. Prognostic implications of intratumoral CD103+ tumor-infiltrating lymphocytes in pulmonary squamous cell carcinoma. Oncotarget. 2017;8(8):13762-9.

73. Hinrichs CS, Borman ZA, Gattinoni L, Yu Z, Burns WR, Huang J, Klebanoff CA, Johnson LA, Kerkar SP, Yang S, et al. Human effector CD8+ T cells derived from naive rather than memory subsets possess superior traits for adoptive immunotherapy. Blood. 2011;117(3):808-14.

74. Hinrichs CS, Borman ZA, Cassard L, Gattinoni L, Spolski R, Yu Z, Sanchez-Perez $L$, Muranski P, Kern SJ, Logun C, et al. Adoptively transferred effector cells derived from naive rather than central memory $\mathrm{CD} 8+\mathrm{T}$ cells mediate superior antitumor immunity. Proc Natl Acad Sci U S A. 2009;106(41):17469-74.

75. Klebanoff CA, Gattinoni L, Torabi-Parizi P, Kerstann K, Cardones AR, Finkelstein SE, Palmer DC, Antony PA, Hwang ST, Rosenberg SA, et al. Central memory self/ tumor-reactive CD8+ T cells confer superior antitumor immunity compared with effector memory T cells. Proc Natl Acad Sci U S A. 2005;102(27):9571-6. 
76. Inozume T, Hanada K, Wang QJ, Ahmadzadeh M, Wunderlich JR, Rosenberg SA, Yang JC. Selection of CD8+PD-1+ lymphocytes in fresh human melanomas enriches for tumor-reactive T cells. J Immunother. 2010;33(9):956-64.

77. Gros A, Robbins PF, Yao X, Li YF, Turcotte S, Tran E, Wunderlich JR, Mixon A, Farid S, Dudley ME, et al. PD-1 identifies the patient-specific CD8(+) tumorreactive repertoire infiltrating human tumors. J Clin Invest. 2014;124(5):2246-59.

78. Blackburn SD, Shin H, Haining WN, Zou T, Workman CJ, Polley A, Betts MR, Freeman GJ, Vignali DA, Wherry EJ. Coregulation of CD8+ T cell exhaustion by multiple inhibitory receptors during chronic viral infection. Nat Immunol. 2009;10(1):29-37.

79. Baitsch L, Legat A, Barba L, Fuertes Marraco SA, Rivals JP, Baumgaertner P, Christiansen-Jucht C, Bouzourene $\mathrm{H}$, Rimoldi D, Pircher $\mathrm{H}$, et al. Extended co-expression of inhibitory receptors by human CD8 T-cells depending on differentiation, antigen-specificity and anatomical localization. PLoS One. 2012;7(2):e30852.

80. Gros A, Parkhurst MR, Tran E, Pasetto A, Robbins PF, llyas S, Prickett TD, Gartner JJ, Crystal JS, Roberts IM, et al. Prospective identification of neoantigen-specific lymphocytes in the peripheral blood of melanoma patients. Nat Med. 2016;22(4):433-8.

81. Cohen CJ, Gartner JJ, Horovitz-Fried M, Shamalov K, Trebska-McGowan K, Bliskovsky W, Parkhurst MR, Ankri C, Prickett TD, Crystal JS, et al. Isolation of neoantigen-specific T cells from tumor and peripheral lymphocytes. J Clin Invest. 2015;125(10):3981-91.

82. Stevanovic S, Pasetto A, Helman SR. Landscape of immunogenic tumor antigens in successful immunotherapy of virally induced epithelial cancer. Science. 2017;356(6334):200-5.

83. Tran E, Turcotte S, Gros A, Robbins PF, Lu YC, Dudley ME, Wunderlich JR, Somerville RP, Hogan K, Hinrichs CS, et al. Cancer immunotherapy based on mutation-specific CD4+ T cells in a patient with epithelial cancer. Science. 2014;344(6184):641-5.

84. Tran E, Robbins PF, Lu YC, Prickett TD, Gartner JJ, Jia L, Pasetto A, Zheng Z, Ray S, Groh EM, et al. T-cell transfer therapy targeting mutant KRAS in Cancer. N Engl J Med. 2016;375(23):2255-62.

85. Skoulidis F, Goldberg ME, Greenawalt DM, Hellmann MD, Awad MM, Gainor JF, Schrock AB, Hartmaier RJ, Trabucco SE, Gay L, et al. STK11/LKB1 mutations and PD-1 inhibitor resistance in KRAS-mutant lung adenocarcinoma. Cancer Discov. 2018;8:822-35.

86. Lee CK, Man J, Lord S, Links M, Gebski V, Mok T, Yang JC. Checkpoint inhibitors in metastatic EGFR-mutated non-small cell lung Cancer-a metaanalysis. J Thorac Oncol. 2017;12(2):403-7.

87. Kato S, Goodman A, Walavalkar V, Barkauskas DA, Sharabi A, Kurzrock R. Hyperprogressors after immunotherapy: analysis of genomic alterations associated with accelerated growth rate. Clin Cancer Res. 2017;23(15): 4242-50.

88. Fang B, Mehran RJ, Heymach JV, Swisher SG. Predictive biomarkers in precision medicine and drug development against lung cancer. Chin J Cancer. 2015;34(1):26.

89. Holmgaard RB, Holmgaard RB. Indoleamine 2,3-dioxygenase is a critical resistance mechanism in antitumor T cell immunotherapy targeting CTLA-4. J Exp Med. 2013;210(7):1389-402.

90. Braun D, Longman RS, Albert ML. A two-step induction of indoleamine 2,3 dioxygenase (IDO) activity during dendritic-cell maturation. Blood. 2005; 106(7):2375-81.

91. Sharma MD, Hou DY, Liu Y, Koni PA, Metz R, Chandler P, Mellor AL, He Y, Munn DH. Indoleamine 2,3-dioxygenase controls conversion of Foxp3+ Tregs to TH17-like cells in tumor-draining lymph nodes. Blood. 2009;113(24):6102-11.

92. Koyama S, Akbay EA, Li YY, Herter-Sprie GS, Buczkowski KA, Richards WG, Gandhi L, Redig AJ, Rodig SJ, Asahina H, et al. Adaptive resistance to therapeutic PD-1 blockade is associated with upregulation of alternative immune checkpoints. Nat Commun. 2016;7:10501.

93. Benci JL, Xu B, Qiu Y, Wu TJ, Dada H, Twyman-Saint Victor C, Cucolo L, Lee DS, Pauken KE, Huang AC, et al. Tumor Interferon Signaling Regulates a Multigenic Resistance Program to Immune Checkpoint Blockade. Cell. 2016; 167(6):1540-1554.e1512.

94. Gettinger S, Choi J, Hastings K, Truini A, Datar I, Sowell R, Wurtz A, Dong W, Cai G, Melnick MA, et al. Impaired HLA class I antigen processing and presentation as a mechanism of acquired resistance to immune checkpoint inhibitors in lung Cancer. Cancer Discov. 2017. https://doi.org/10.1158/21598290.CD-17-0593.

95. Zaretsky JM, Garcia-Diaz A, Shin DS, Escuin-Ordinas H, Hugo W, Hu-Lieskovan S, Torrejon DY, Abril-Rodriguez G, Sandoval S, Barthly L, et al. Mutations associated with acquired resistance to PD-1 blockade in melanoma. N Engl J Med. 2016;375(9):819-29.

96. Butcher EC, Picker LJ. Lymphocyte homing and homeostasis. Science. 1996; 272(5258):60-6.

97. Masopust D, Schenkel JM. The integration of T cell migration, differentiation and function. Nat Rev Immunol. 2013;13(5):309-20.

98. Zehn D, Lee SY, Bevan MJ. Complete but curtailed T-cell response to very low-affinity antigen. Nature. 2009:458(7235):211-4.

99. Yan X, Wang L, Zhang R, Pu X, Wu S, Yu L, Meraz IM, Zhang X, Wang JF، Gibbons $\mathrm{DL}$, et al. Overcoming resistance to anti-PD immunotherapy in a syngeneic mouse lung cancer model using locoregional virotherapy. Oncoimmunol. 2018;7(1):e1376156.

100. Ribas A, Dummer R, Puzanov I, VanderWalde A, Andtbacka RHI, Michielin O, Olszanski AJ, Malvehy J, Cebon J, Fernandez E, et al. Oncolytic Virotherapy Promotes Intratumoral T Cell Infiltration and Improves Anti-PD-1 Immunotherapy. Cell. 2017;170(6):1109-1119.e1110.

101. Tang H, Wang Y, Chlewicki LK, Zhang Y, Guo J, Liang W, Wang J, Wang X, Fu YX. Facilitating T cell infiltration in tumor microenvironment overcomes resistance to PD-L1 blockade. Cancer Cell. 2016;29(3):285-96.

102. Bald T, Landsberg J, Lopez-Ramos D, Renn M, Glodde N, Jansen P, Gaffal E, Steitz J, Tolba R, Kalinke U, et al. Immune cell-poor melanomas benefit from PD-1 blockade after targeted type I IFN activation. Cancer Discov. 2014;4(6):674-87.

103. Overman MJ, McDermott R, Leach JL, Lonardi S, Lenz HJ, Morse MA, Desai J, Hill A, Axelson M, Moss RA, et al. Nivolumab in patients with metastatic DNA mismatch repair-deficient or microsatellite instability-high colorectal cancer (CheckMate 142): an open-label, multicentre, phase 2 study. Lancet Oncol. 2017;18(9):1182-91.

104. McLaughlin J, Han G, Schalper KA, Carvajal-Hausdorf D, Pelekanou V, Rehman J, Velcheti V, Herbst R, LoRusso P, Rimm DL. Quantitative assessment of the heterogeneity of PD-L1 expression in non-small-cell lung Cancer. JAMA Oncol. 2016;2(1):46-54.

105. Nakamura S, Hayashi K, Imaoka Y, Kitamura Y, Akazawa Y, Tabata K, Groen R, Tsuchiya T, Yamasaki N, Nagayasu T, et al. Intratumoral heterogeneity of programmed cell death ligand-1 expression is common in lung cancer. PLoS One. 2017;12(10):e0186192.

106. Pinato DJ, Shiner RJ, White SD, Black JR, Trivedi P, Stebbing J, Sharma R, Mauri FA. Intra-tumoral heterogeneity in the expression of programmeddeath (PD) ligands in isogeneic primary and metastatic lung cancer: implications for immunotherapy. Oncoimmunol. 2016;5(9):e1213934.

107. Kamphorst AO, Pillai RN, Yang S, Nasti TH, Akondy RS, Wieland A, Sica GL, Yu K, Koenig L, Patel NT, et al. Proliferation of PD-1+ CD8 T cells in peripheral blood after PD-1-targeted therapy in lung cancer patients. Proc Natl Acad Sci U S A. 2017;114(19):4993-8.

108. Kepp O, Senovilla L, Vitale I, Vacchelli E, Adjemian S, Agostinis P, Apetoh L, Aranda F, Barnaba $V$, Bloy N, et al. Consensus guidelines for the detection of immunogenic cell death. Oncoimmunol. 2014;3(9):e955691.

109. Galluzzi L, Kepp O, Kroemer G. Immunogenic cell death in radiation therapy. Oncoimmunol. 2013;2(10):e26536.

110. Gameiro SR, Jammeh ML, Wattenberg MM, Tsang KY, Ferrone S, Hodge JW. Radiation-induced immunogenic modulation of tumor enhances antigen processing and calreticulin exposure, resulting in enhanced T-cell killing. Oncotarget. 2014;5(2):403-16.

111. Beyranvand Nejad E, van der Sluis TC, van Duikeren S, Yagita H, Janssen GM, van Veelen PA, Melief CJ, van der Burg SH, Arens R. Tumor eradication by cisplatin is sustained by CD80/86-mediated Costimulation of CD8+ T cells. Cancer Res. 2016;76(20):6017-29.

112. Suzuki Y, Mimura K, Yoshimoto Y, Watanabe M, Ohkubo Y, Izawa S, Murata K, Fujii H, Nakano T, Kono K. Immunogenic tumor cell death induced by chemoradiotherapy in patients with esophageal squamous cell carcinoma. Cancer Res. 2012;72(16):3967-76.

113. Gandhi L, Rodriguez-Abreu D, Gadgeel S, Esteban E, Felip E, De Angelis F, Domine M, Clingan P, Hochmair MJ, Powell SF, et al. Pembrolizumab plus chemotherapy in metastatic non-small-cell lung Cancer. N Engl J Med. 2018; 378(22):2078-92.

114. Fesnak $A D$, June $C H$, Levine BL. Engineered T cells: the promise and challenges of cancer immunotherapy. Nat Rev Cancer. 2016;16(9):566-81. 